\title{
Jan Poleszczuk
}

UNIWERSYTET W BIAŁYMSTOKU

E-MAIL: JAN.POLESZCZUK@GMAIL.COM

\section{DECYZJE EDUKACYJNE MATURZYSTÓW. KONTEKST SPOŁECZNY I INDYWIDUALNE POSTAWY MŁODZIEŻY BIAŁEGOSTOKU WOBEC WYKSZTAŁCENIA WYŻSZEGO}

\section{Wprowadzenie}

Proces podejmowania decyzji jest złożoną sekwencją czynności wymagających umiejętności pozyskiwania i przetwarzania informacji o alternatywach związanych z problemem decyzyjnym, przewidywania konsekwencji i realistycznej oceny dostępności alternatyw, jak i własnych możliwości. Decyzje wyrażają nasze postawy względem obiektów (problemów), których dotyczą. Na podstawie posiadanej wiedzy (informacji) o alternatywach oraz preferencji określających motywację do działania na rzecz osiągnięcia założonych celów dokonujemy wyboru i podejmujemy związane z nim działania, które mają - z założenia - przynieść przewidywany i pożądany efekt. Nie zawsze jednak decyzje okazują się sukcesem, czasem podejmujemy decyzje błędne. Jeśli sytuacje decyzyjne się powtarzają, możemy uczyć się na własnych błędach i sukcesach. Wybór kierunku studiów, a wcześniej decyzja o podjęciu dalszej nauki lub zakończeniu kształcenia na maturze - to być może pierwsza poważna decyzja w życiu młodych ludzi. Konsekwencje tych decyzji nie zawsze dają się przewidzieć, wybór drogi życiowej zależy nie tylko od własnych preferencji, ambicji i zdolności, wiedzy i posiadanych informacji, ale również od tego, jaki wpływ na dokonywane wybory wywierają inne osoby (rodzice, nauczyciele, koledzy). Wydaje się jednak, że podstawową funkcję w decyzjach edukacyjnych maturzystów odgrywają czynniki „charakteru”: tego, czy młodzi ludzie planują przyszłość, jak trafnie umieją ją przewidzieć, czy i w jakim stopniu potrafią kontrolować 
własne życie, czyich rad są skłonni słuchać. Czy młodzi ludzi podejmują decyzje rozsądnie, z namysłem, racjonalnie czy przeciwnie - kierują się modą, emocjami lub opinią kolegów? Jakie konsekwencje dla postrzegania atrakcyjności studiów wyższych, wartościowania wyższego wykształcenia w perspektywie postrzeganych szans na sukces życiowy ma indywidualny „styl podejmowania decyzji” edukacyjnych przez maturzystów?

\section{Model sytuacji decyzyjnej - indywidualne postawy i kontekst społeczny}

Maturzyści stanowią interesującą kategorię socjologiczną ze względu na specyficzny splot cech demograficznych, fazę cyklu życiowego oraz złożoność kontekstu społecznego, w którym krzyżują się relacje pierwotne (rodzice), instytucjonalne (nauczyciele) i relacje z grupą rówieśniczą (środowisko szkolne).

Po pierwsze, maturzyści tworzą homogeniczną wiekowo grupę, która przeszła przez wcześniejsze (zuniformizowane organizacyjnie i programowo) szczeble systemu edukacyjnego. Ze względu na funkcję reprodukcji struktury społecznej przez system edukacyjny grupę maturzystów charakteryzuje większy odsetek rodziców zajmujących wyższe pozycje społeczne, lepiej sytuowanych, przekazujących dzieciom swoje aspiracje, wiedzę kulturową, „kapitał społeczny”. Młodzież szkolna na tym poziomie rozwoju indywidualnego dysponuje wystarczającym zasobem doświadczeń pozwalających na rozpoznanie w zachowaniach, dokonywanych wyborach, interakcjach społecznych własnych, względnie trwałych i wyraźnych cech charakteru, stylu funkcjonowania w szkole, stylu pracy, własnych zainteresowań, pozycji w grupach rówieśniczych. Zróżnicowanie osiągnięć szkolnych (punkty uzyskane na egzaminie maturalnym) w większym stopniu - z uwagi na wspólne czynniki środowiskowe - wyrażać mogą indywidualne (wrodzone) predyspozycje intelektualne i emocjonalne.

Po drugie, młodzież szkół średnich znajduje się w szczególnej (krytycznej) fazie cyklu życiowego - fazie uzyskiwania względnej autonomii życiowej, poszerzania zakresu indywidualnych decyzji dotyczących zainteresowań, stylu życia, relacji społecznych. Mimo to, podlegają nadal istotnym zależnościom egzystencjalnym od rodziców; muszą funkcjonować w systemie dyscypliny szkolnej, podlegając ocenie i kontroli nauczycieli oraz uczestniczą $\mathrm{w}$ grupach rówieśniczych nawiązując relacje interpersonalne związane z przynależnością do grup towarzyskich i zajmowaną 
w nich pozycją. Środowisko szkolne tworzy złożony i dynamiczny układ odniesienia, w ramach którego kształtują się postawy młodych ludzi.

Po trzecie, decyzje edukacyjne maturzystów mają specyficzne cechy, na które warto zwrócić uwagę. Decyzja o kontynuowaniu nauki na studiach wyższych i wybór kierunku kształcenia nie należy do klasy decyzji powtarzalnych i odwracalnych, w których koszty popełnienia błędu nie są duże. Są to decyzje o charakterze „inwestycyjnym”, których efekty ujawnią się w dłuższej perspektywie czasu zależnie od poziomu satysfakcji z wybranego zawodu, sytuacji na rynku pracy, poziomu uzyskiwanych dochodów. Perspektywa czasowa decyzji wiąże się z dużym zakresem niepewności i sprawia, że decyzje indywidualne mogą być silnie uzależnione od preferencji rodziców, wiedzy nauczycieli, wpływu rówieśników, mody oraz mediów. Proces decyzyjny może być konfliktogenny, gdy między tymi alternatywnymi źródłami autorytetu (rodzice, nauczyciele, rówieśnicy) mogą wystąpić różnice lub ich wpływ będzie kolidował $\mathrm{z}$ indywidualnymi preferencjami ucznia.

Wymienione aspekty sytuacji decyzyjnej maturzystów zostały ujęte w postaci prostego modelu zawierającego sześć podstawowych komponentów (rysunek 1). Z nimi zestawiono czynniki odnoszące się do postaw związanych z procesem podejmowania decyzji edukacyjnych (tabela 1).

Rysunek 1. Sytuacja decyzyjna maturzysty - „aktorzy” kontekstu społecznego i perspektywa czasowa

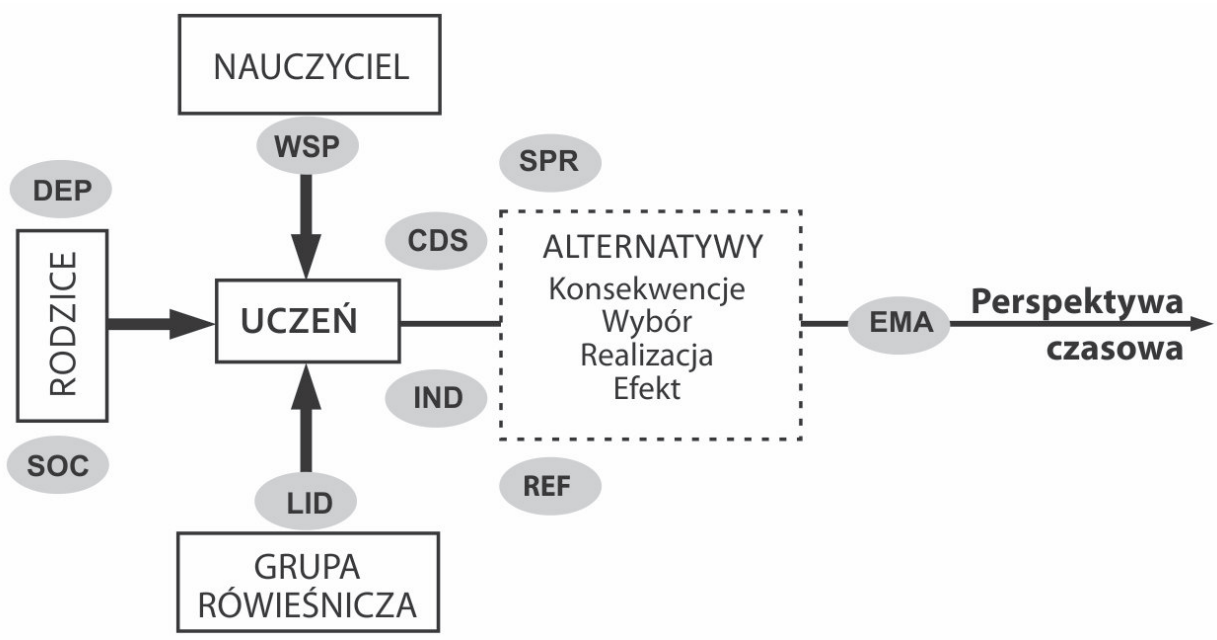


Tabela 1. Komponenty sytuacji decyzyjnej i związane z nimi czynniki (postawy)

\begin{tabular}{|l|c|}
\hline \multicolumn{1}{|c|}{ Komponent sytuacji decyzyjnej } & $\begin{array}{c}\text { Czynnik } \\
\text { (postawa) }\end{array}$ \\
\hline $\begin{array}{l}\text { Perspektywa czasowa. Postawa względem przyszłości, poczucie kontroli nad } \\
\text { życiem, syndrom koncentracji na teraźniejszości (Carpe Diem Syndorm), } \\
\text { dyskontowanie czasu, niecierpliwość, ograniczony horyzont planowania }\end{array}$ & CDS \\
\hline $\begin{array}{l}\text { Styl podejmowania decyzji (refleksyjność związana z przestrzenią alternatyw, } \\
\text { konsekwencji, wyborami i dążeniem do osiągnięcia zakładanych celów) } \\
\text { - refleksyjna postawa odpowiadająca Weberowskiej koncepcji człowieka } \\
\text { „racjonalnego” }\end{array}$ & REF \\
\hline $\begin{array}{l}\text { Orientacja na efekty podejmowanych decyzji. Reakcja na sukces i porażkę } \\
\text { (wewnętrzne i autonomiczne źródło satysfakcji i odpowiedzialności) }\end{array}$ & EMA \\
\hline $\begin{array}{l}\text { Poczucie indywidualnej autonomii i sprawstwa, asertywny stosunek do własnych } \\
\text { decyzji }\end{array}$ & SPR, LID \\
\hline $\begin{array}{l}\text { Wpływ kontekstu społecznego na proces decyzyjny (orientacja na pozycję } \\
\text { w grupie i konformistyczny wymiar procesów decyzyjnych) }\end{array}$ & LID, SOC \\
\hline $\begin{array}{l}\text { Wpływ rodziców - zależność od ich oczekiwań, kontrola zachowania oraz } \\
\text { poczucie wsparcia rodzicielskiego w trudnych sytuacjach życiowych }\end{array}$ & DEP, WSP \\
\hline
\end{tabular}

Przedstawiona w artykule analiza uwarunkowań i konsekwencji indywidualnych decyzji edukacyjnych mieści się w zakresie socjologii edukacji, która w ostatnich dekadach była skoncentrowana na problematyce zmian instytucjonalnych $\mathrm{w}$ kontekście przemian ustrojowych [Zahorska 2004], nierówności [Sawiński 2008; Zawistowska 2012, 2014], przejawów „patologii” [NIK 2013]. „W związku z tym - zauważa Mirosław Szymański - niemal całkowicie zaniechano badań nad selekcjami szkolnymi i ich społecznymi uwarunkowaniami” [Szymański 2013: 12]. Proces decyzyjny związany z wyborem ścieżki kształcenia wyższego jest właśnie procesem „selekcyjnym”, który odpowiada na presje środowiskowe (w tym również regionalne uwarunkowania społeczne i kulturowe) i wywołuje czasem trudne do przewidzenia konsekwencje indywidualne i społeczne. W ostatnich latach pojawiają się prace, w których procesy „selekcyjne” stają się głównym przedmiotem badań [Kamieniecka 2015; Węziak-Białowolska 2010; Węziak-Białowolska; Kotowska 2014]. 


\section{Indywidualne postawy i style podejmowania decyzji edukacyjnych}

Uzyskane $\mathrm{w}$ badaniu ${ }^{1}$ wyniki pozwoliły zidentyfikować założone w modelu sytuacji decyzyjnej postawy (tabela 2).

Tabela 2. Postawy (czynniki) i wyrażające je wskaźniki w danym roku (eksploracyjna analiza czynnikowa ${ }^{2}$ )

\begin{tabular}{|l|c|c|c|c|}
\hline Procent osób akceptujących stwierdzenie (wskaźnik): & $\mathbf{2 0 1 0}$ & $\mathbf{2 0 1 3}$ & $\mathbf{2 0 1 5}$ & $\mathbf{\%} / \mathrm{FL}$ \\
\hline CDS (Carpe Diem Syndrome) & & & & $\mathbf{1 1 , 4}$ \\
\hline $\begin{array}{l}\text { Nie mam jakiegoś wyraźnego planu na najbliższe } \\
\text { lata }\end{array}$ & 33,8 & 30,8 & 35,9 & 0,69 \\
\hline $\begin{array}{l}\text { W dzisiejszym świecie trudno mieć dobry plan } \\
\text { na życie, zbyt wiele zależy od przypadku }\end{array}$ & 51,0 & 49,8 & 59,5 & 0,67 \\
\hline $\begin{array}{l}\text { Nie myślę o dalszej przyszłości, staram się żyć } \\
\text { chwilą, tym, co się aktualne dzieje }\end{array}$ & 26,3 & 25,7 & 31,3 & 0,61 \\
\hline $\begin{array}{l}\text { Nie planuję na dłuższą metę, gdyż przekonałem się, że } \\
\text { z tych planów z reguły nic nie wychodzi }\end{array}$ & 35,1 & 36,0 & 36,7 & 0,61 \\
\hline $\begin{array}{l}\text { Czasem wydaje mi się, że w moim życiu nie mam zbyt } \\
\text { wielu możliwości wyboru i będzie co ma być }\end{array}$ & 39,2 & 36,9 & 37,4 & 0,61 \\
\hline $\begin{array}{l}\text { Trudno mi sobie wyobrazić swoją sytuację życiową } \\
\text { za 1o lat }\end{array}$ & 59,5 & 54,6 & 60,8 & 0,60 \\
\hline Życia nie da się zaplanować & 61,7 & 59,6 & 57,7 & 0,59 \\
\hline $\begin{array}{l}\text { Często mi się zdarza, że zmieniam plany i kieruję się tym, } \\
\text { co się aktualnie dzieje }\end{array}$ & 45,6 & 44,0 & 45,4 & 0,44 \\
\hline REF (Refleksyjność decyzyjna) & 65,2 & 67,1 & 64,7 & 0,70 \\
\hline $\begin{array}{l}\text { Gdy coś planuję, biorę pod uwagę jak najwięcej alternatyw, } \\
\text { opcji, możliwości }\end{array}$ & 63,5 & 63,0 & 0,64 \\
\hline $\begin{array}{l}\text { Gdy podejmuję decyzję staram się rozważać } \\
\text { wszystkie przyszłe konsekwenje wyborów }\end{array}$ & $\mathbf{9}$ & 63,3 & 60,6 & 0,53 \\
\hline $\begin{array}{l}\text { Gdy już się na coś zdecyduję, to wytrwale dążę } \\
\text { do celu, skupiam na nim całą uwagę }\end{array}$ & & & & \\
\hline
\end{tabular}

Informacje o badaniu znajdują się w nocie metodologicznej - „Specyfikacja badania”.

2 Informacje o metodologii analizy znajdują się w nocie metodologicznej „Analiza czynnikowa”. 
cd. Tabela 2.

\begin{tabular}{|c|c|c|c|c|}
\hline $\begin{array}{l}\text { Gdy coś zamierzam zrobić, dużo czasu poświęcam } \\
\text { zrobieniu szczegółowego planu }\end{array}$ & 32,3 & 33,6 & 36,8 & 0,43 \\
\hline EMA (Emocjonalna autonomia) & & & & 6,5 \\
\hline $\begin{array}{l}\text { Gdy coś zaplanuję, to lubię, gdy osiągnę dokładnie to, co } \\
\text { zaplanowałem }\end{array}$ & 86,1 & 88,2 & 81,2 & 0,67 \\
\hline $\begin{array}{l}\text { Cenię u innych konsekwencję w działaniach, dążenie do } \\
\text { jasnych celów }\end{array}$ & 86,8 & 87 & 83,3 & 0,62 \\
\hline $\begin{array}{l}\text { Gdy mi się nie udaje osiągnąć zamierzonych celów, } \\
\text { odczuwam złość na siebie }\end{array}$ & 68,7 & 71,3 & 65,4 & 0,61 \\
\hline LID (Orientacja na przywództwo) & & & & 5,0 \\
\hline $\begin{array}{l}\text { W sytuacjach problemowych lubię podejmować decyzje w } \\
\text { imieniu grupy i brać za nią odpowiedzialność }\end{array}$ & 30,2 & 29,7 & 32,0 & 0,71 \\
\hline $\begin{array}{l}\text { W porównaniu z moimi kolegami mam więcej szans na } \\
\text { zrealizowanie planów życiowych }\end{array}$ & 25,9 & 27,2 & 28,5 & 0,67 \\
\hline $\begin{array}{l}\text { Mogę powiedzieć, że koledzy (koleżanki) często mnie } \\
\text { naśladują }\end{array}$ & 18,9 & 18,4 & 21,2 & 0,52 \\
\hline IND (Indywidualizm) & & & & 4,1 \\
\hline $\begin{array}{l}\text { Wydaje mi się, że aby dojść do czegoś w życiu, muszę liczyć } \\
\text { tylko na siebie }\end{array}$ & 60,3 & 65,4 & 65,4 & 0,64 \\
\hline $\begin{array}{l}\text { Nie lubię, gdy inni wtrącają się w moje sprawy i udzielają } \\
\text { mi „dobrych rad” }\end{array}$ & 53,3 & 54,0 & 56,8 & 0,52 \\
\hline $\begin{array}{l}\text { Aby osiągnąć zamierzone cele, zrealizować swe plany } \\
\text { życiowe nie należy zbytnio ufać innym }\end{array}$ & 46,0 & 48,4 & 50,4 & 0,51 \\
\hline $\begin{array}{l}\text { Gdy się coś komuś nie udaje, to zwykle sam jest sobie } \\
\text { winien }\end{array}$ & 34,8 & 39,1 & 38,8 & 0,45 \\
\hline $\begin{array}{l}\text { Nie lubię ludzi, którzy przywiązują nadmierną uwagę do } \\
\text { drobiazgów, szczegółów }\end{array}$ & 33,0 & 36,7 & 41,5 & 0,41 \\
\hline SOC (Orientacja na kontekst społeczny) & & & & 3,7 \\
\hline $\begin{array}{l}\text { Nie zawsze potrafię przewidzieć konsekwencje } \\
\text { podejmowanych decyzji }\end{array}$ & 51,6 & 50,7 & 48,0 & 0,67 \\
\hline Nie lubię robić kilku rzeczy jednocześnie, to mnie rozprasza & 37,3 & 38,4 & 38,7 & 0,59 \\
\hline
\end{tabular}


cd. Tabela 2.

\begin{tabular}{|l|c|c|c|c|}
\hline $\begin{array}{l}\text { Często podejmując decyzje zastanawiam się, jak w takiej } \\
\text { sytuacji postąpiliby moi koledzy (koleżanki) }\end{array}$ & 21,2 & 22,1 & 26,3 & 0,46 \\
\hline DEP (Poczucie zależności) & & & & $\mathbf{3 , 7}$ \\
\hline $\begin{array}{l}\text { Moi rodzice mają wyraźne oczekiwania co do tego, jak się } \\
\text { potoczy moje życie }\end{array}$ & 33,2 & 37,8 & 40,1 & 0,82 \\
\hline $\begin{array}{l}\text { Mam wrażenie, że rodzice za bardzo chcą kontrolować } \\
\text { moje życie }\end{array}$ & 30,6 & 30,1 & 33,0 & 0,81 \\
\hline SPR (Sprawstwo) & 30,0 & 33,5 & 32,8 & 0,62 \\
\hline $\begin{array}{l}\text { Dziś więcej zależy w życiu od indywidualnego wysiłku i } \\
\text { ambicji niż od układów, znajomości }\end{array}$ & 23,3 & 27,5 & 28,0 & 0,59 \\
\hline $\begin{array}{l}\text { Nigdy nie żałowałem podjętych decyzji } \\
\text { WSP (Wsparcie społeczne) }\end{array}$ & 58,4 & 66,8 & 65,8 & 0,75 \\
\hline $\begin{array}{l}\text { Przed podjęciem ważnej decyzji staram się porozmawiać } \\
\text { z osobą, do której mam zaufanie }\end{array}$ & 67,3 & 60,6 & 0,53 \\
\hline $\begin{array}{l}\text { W trudnej sytuacji mogę liczyć na wsparcie rodziców, ich } \\
\text { znajomości, możliwości zawodowe }\end{array}$ & 58,0 & $\mathbf{3 , 1}$ \\
\hline
\end{tabular}

\% - procent wyjaśnionej wariancji przez czynnik; FL - (factor loading) - znaczenie wskaźnika (stwierdzenia) w czynniku. Uwzględnione w tabeli wskaźniki uporządkowane są według FL, a więc znaczenia danego wskaźnika w czynniku. Czynniki wymienione są w kolejności ich znaczenia w redukcji macierzy kowariancji.

CDS (Carpe Diem Syndrome)³. Cechą zasadniczą syndromu jest postawa zorientowana na życie chwilą bieżącą. Osoba przejawiająca wysoki poziom syndromu CDS nie ma wyraźnego planu na najbliższe lata, nie planuje na dłuższą metę, gdyż jest przekonana, że nie uda się jej zrealizować planów. Przyznaje, że nie potrafi wyobrazić sobie swojej sytuacji życiowej za 10 lat. Właściwie przyjmuje postawę pasywną, podporządkowuje się sytuacji. Jeśli ma jakieś plany, to zmienia je i kieruje się tym, co się aktualnie dzieje. Na uwagę zasługuje to, że w tym syndromie łączą się dwie sprzeczne tendencje do postrzegania świata w kategoriach przypadku (nie ma sensu

3 Syndrom Carpe Diem stał się od niedawna przedmiotem badań psychologów, zob. [Sobol-Kwapińska 2013, 2016]. 
planowanie, gdy zbyt wiele zależy od przypadku) oraz fatalizmu (nie mam wielu możliwości wyboru i będzie co ma być). Syndrom Carpe Diem może mieć kilka różnych interpretacji. Z pewnością może być związany z silnym dyskontowaniem przyszłości, trudnością z oczekiwaniem na odroczone nagrody (długoterminowe konsekwencje decyzji), impulsywnością, która wyklucza mechanizm samokontroli niezbędny do planowania przyszłości. Na uwagę również zasługuje wyraźna silna wrażliwość na zmieniające się okoliczności. Wydaje się jednak, że podstawowe znaczenie dla interpretacji tego syndromu może mieć hipoteza wiążąca CDS z poczuciem utraty kontroli nad rzeczywistością. Negatywną stroną CDS jest poczucie kontroli nad własnymi działaniami (oczywiście może być ono iluzją kontroli prowadzącą do nierealistycznej percepcji sytuacji i własnych kompetencji).

REF (Refleksyjność decyzyjna). Osoba cechująca się wysokimi wartościami REF prezentuje klasyczny zestaw cech postulowanych w modelu racjonalności, w którym nie tylko liczy się końcowy efekt postępowania, ale również proces podejmowania decyzji. Z pewnością planowanie wymaga rozważania wielu dostępnych alternatyw, analizy konsekwencji różnych opcji. W efekcie może powstać szczegółowy plan, na sporządzenie którego jednostka gotowa jest poświęcić wiele czasu. Refleksyjność decyzyjna wymaga niewątpliwie dużego zaangażowania zasobów poznawczych, uwagi, skupienia, zdolności dokonywania analizy, przewidywania. Jest więc postawą niezwykle wymagającą kognitywnie. Ważne jest również to, że proces refleksyjnego planowania kończy się podjęciem wysiłku wcielenia go w życie - jednostka wytrwale dąży do celu i skupia na nim całą uwagę. Negatywną stroną czynnika REF może być działanie całkowicie losowe („rzut monetą”) lub zachowanie rutynowe, nawykowe, wynikające z silnej habitualizacji wzorca reagowania na sytuację - w sumie niewymagające zaangażowania zasobów poznawczych i motywacyjnych.

EMA (Emocjonalna autonomia). Osiągnięcie zaplanowanych celów (sukces) jest dla jednostki źródłem satysfakcji, nagrodą. Natomiast porażka (gdy nie udaje osiągnąć zaplanowanych celów) wywołuje „złość na siebie”. Sukcesy i porażki są dla jednostki źródłem emocjonalnych wzmocnień (nagród i kar). Planowanie i konsekwentne dążenie do „jasnych celów” jest tym, co jednostka ceni u innych (w domyśle również i u siebie). Z czynnikiem EMA koreluje również (choć nie jest to specyficzna dla tego czynnika składowa) przekonanie o wytrwałym dążeniu do celu, na którym skupiona jest uwaga, oraz przekonanie, że aby dojść do czegoś w życiu, trzeba liczyć na siebie, choć przed podjęciem ważnej decyzji warto porozmawiać z zaufaną osobą. W sumie konsekwentne działanie w realizacji planów jest świadec- 
twem emocjonalnej autonomii zarówno z odniesieniu do sukcesów, jak i porażek. „Złość na siebie” jest świadectwem podmiotowej atrybucji nagród i kar, a więc również podstawą efektywnej habitulaizacji zachowań. Negatywną stroną czynnika EMA może być całkowite niezainteresowanie indywidualnymi sukcesami, zaś atrybucja może przyjąć odniesienie zewnętrzne - może nim być pochwała, uznanie ze strony innych lub przerzucenie na nich winy za porażkę (usprawiedliwienie).

LID (Orientacja na przywództwo). Osoby z wysokimi wartościami czynnika LID przejawiają skłonność do przyjmowania roli przywódcy w grupie - w sytuacjach trudnych lubią podejmować decyzje w imieniu grypy oraz brać za nią odpowiedzialność, mają poczucie, że są liderami, których inni naśladują. Przekonani są również, że w porównaniu z kolegami mają więcej szans na zrealizowanie planów życiowych. Podzielają także przekonanie (niespecyficzne dla tego czynnika), że osoby, którym się nie udaje, same są sobie winne; nie rozprasza ich robienie kilku rzeczy na raz oraz gdy podejmują decyzję biorą pod uwagę punkt widzenia kolegów (koleżanek). Słowem, LID prezentuje klasyczny syndrom lidera grupy ze skłonnością do dominacji i umiejętnością przewidywania zachowań innych członków grupy. Przeciwieństwem LID jest przyjmowanie postawy naśladowcy, konformisty, pozycji podporządkowanej w grupie społecznej.

IND (Indywidualizm). Postawa indywidualistyczna łączy w sobie typową wiązkę cech osoby poszukującej autonomii: nie lubi, gdy inni wtrącają się w jego sprawy i udzielają „dobrych rad”. Osiągnięcie zamierzonych celów, planów życiowych wymaga tego, aby zbytnio nie ufać innym. Nie muszą oni bowiem udzielać „dobrych rad” bezinteresownie, szczególnie, gdy plany życiowe mogą ze sobą kolidować. W związku z tymi konfliktowymi relacjami jednostka, aby dojść do czegoś w życiu musi liczyć tylko na siebie i jeśli nie udaje się jej, to zwykle sama jest sobie winna. Wydaje się, że czynnik IND charakteryzuje postawę "gracza strategicznego", który powinien kierować się swymi indywidualnymi interesami, mieć ograniczone zaufanie do innych, ich „dobrych rad" i całkowicie odpowiadać za swoje sukcesy i porażki. Przeciwieństwem "gracza strategicznego" jest osoba $\mathrm{w}$ większym stopniu korzystająca $\mathrm{z}$ „dobrych rad”, nastawiona kooperacyjnie, z większym zaufaniem odnosząca się do innych członków grupy.

SOC (Orientacja na kontekst społeczny). W przeciwieństwie do czynnika LID, który również był zorientowany na relacje społeczne, czynnik SOC dotyczy podejmowania decyzji. Charakteryzuje on jednostki mające trudności z przewidywaniem konsekwencji podejmowanych decyzji (co utrudnia przyjęcie postawy refleksyjnej) oraz utrzymaniem uwagi i kon- 
troli, gdy muszą robić kilka rzeczy jednocześnie - wówczas się rozpraszają. W tej sytuacji refleksja nad tym, jak w sytuacji decyzyjnej postąpiliby koledzy i koleżanki pozwala na przełamanie trudności z przewidywaniem i rozpraszaniem uwagi. Wystarczy sprawny mechanizm przyjmowania perspektywy innych aktorów, działanie z większą empatią, skłonność do imitacji, wykorzystanie zasobów wiedzy wspólnej, zaufanie (przed podjęciem decyzji osoby silnie zorientowane na kontekst społeczny starają się rozmawiać z zaufaną osobą - wskaźnik niespecyficzny dla SOC). Nie zawsze decyzje te muszą być - z punktu widzenia jednostki - dla niej korzystne. Stąd osoby z SOC odrzucają stwierdzenie "Nigdy nie żałowałem podjętych decyzji”, choć nie jest to wskaźnik specyficzny. Postawę przeciwną prezentować będą osoby radzące sobie z przewidywaniem konsekwencji decyzji - nie muszą one wykorzystywać kontekstu społecznego jako układu odniesienia stabilizującego decyzje. W efekcie mniej im się przydarzy pomyłek i będą miały mniej okazji do żałowania podjętych decyzji.

DEP (Poczucie zależności). Rodzice są jednym z podstawowych „aktorów” w sytuacji decyzyjnej maturzysty. W 2015 roku 40\% maturzystów stwierdziło, że rodzice mają „wyraźne oczekiwania” co do tego, jak potoczy się ich życie. W opinii 33\% uczniów rodzice „za bardzo chcą kontrolować moje życie”. Wydaje się, że korelacja oczekiwań i kontroli jest naturalna. Tylko gdy nie ma się „wyraźnych oczekiwań”, można sobie pozwolić na większą obojętność wobec tego, jakie plany życiowe ma dziecko, czy będzie studiować i jaki kierunek, jak się uczy, z kim i jak spędza czas wolny. Wysokie oczekiwania rodziców (ich ambicje) oraz skłonność do nadmiernej kontroli mogą prowadzić do sytuacji konfliktowych, szczególnie istotnych w kontekście fazy cyklu życiowego, w której młodzi ludzie dążą do poszerzenia zakresu autonomii.

SPR (Sprawstwo). Podejmowanie decyzji i wprowadzanie w życie posiadanych planów (strategii) wiąże się z poczuciem sprawstwa, tego że się kreuje lub wywołuje pożądane stany rzeczy. Poczucie sprawstwa implikuje, że indywidualny wysiłek i ambicja jednostki prowadzi do osiągnięcia zamierzonych celów, że mniejszą rolę odgrywają układy i znajomości. Poczucie sprawstwa nie musi być powiązane $z$ indywidualizmem (IND), choć z nim podziela (niespecyficzne) przekonanie o tym, że za porażki jednostka jest sama sobie winna i niechętny stosunek do „dobrych rad”. Poczucie sprawstwa zakłada przekonanie, że życie daje się zaplanować i że robienie szczegółowego planu jest rzeczą rozsądną, dającą większe szanse na przewidywany sukces. Osoby cechujące się wysokim poczuciem sprawstwa częściej 
akceptują stwierdzenie: „Nigdy nie żałowałem podjętych decyzji”. Trudno rozstrzygnąć, czy częściej podejmują trafne decyzje i nie muszą ich żałować, czy też poczucie sprawstwa jest niezależnym źródłem satysfakcji, nawet gdy decyzje okazują się niefortunne. Warto jednak zauważyć, że poczucie sprawstwa może być postawą odnoszącą się do względnie krótkiego horyzontu czasowego. Osoby z wysokim poczuciem sprawstwa podzielają charakterystyczne dla CDS (Carpe Diem Syndrome) przekonanie, że często zmieniają plany i kierują się tym, co się aktualnie dzieje oraz nie myślą o dalszej przyszłości. Może to świadczyć o dużej elastyczności decyzyjnej, zdolności do rewidowania planów w świetle nowych informacji. Plany mają zaś status lokalnych strategii, które mogą ulec zmianie w wyniku zmiany w zasobach informacyjnych jednostki. Przeciwieństwem postawy SPR jest liczenie na układy i znajomości, większa sztywność planów i odporność na adaptację.

WSP (Wsparcie społeczne). Wydaje się, że czynnik wsparcia społecznego odnosi się do „kapitału”, którym może się posłużyć jednostka. Przed podjęciem „ważnej decyzji” stara się „porozmawiać z osobą, do której ma zaufanie" (ponad 65\% uczniów składa taką deklarację). Nie muszą to być rodzice, osobą zaufaną mogą być również nauczyciele lub przyjaciel w grupie rówieśniczej. W przypadku „trudnej sytuacji” może zaś liczyć na wsparcie rodziców, ich „znajomości, możliwości zawodowe” - wsparcie nepotystyczne. To „wsparcie” może być ważnym składnikiem motywacyjnym. Osoby, które mogą liczyć na wsparcie społeczne, częściej wyrażają przekonanie (niespecyficzne dla tego czynnika), że gdy się na coś zdecydują, to wytrwale dążą do celu, skupiając na nim całą uwagę. Interesujące jest to, że częściej nie lubią osób, które przywiązują nadmierną uwagę do drobiazgów, szczegółów. Wydaje się, że idealnym typem „wsparcia” byłoby wsparcie carte blanche. Przeciwieństwem WSP byłaby sytuacja, w której jednostka nie ma możliwości porozmawiania $\mathrm{z}$ osobą zaufaną i nie może liczyć na wsparcie rodziców, których kapitał społeczny może być mały (niskie wykształcenie, wykonywanie zawodu niedającego dużych możliwości nawiązywania korzystnych relacji społecznych).

\section{Wybór studiów wyższych - kryteria decyzyjne}

Przy wyborze uczelni, miejsca studiowania (Białystok lub inne miasto w Polsce) oraz kierunku studiów maturzyści mogą się kierować różnymi kryteriami, jakie są związane z ofertą dydaktyczną. 
Tabela 3. Charakterystyki ważne przy wyborze uczelni lub kierunku studiów (model regresji logistycznej)*

\begin{tabular}{|l|l|l|l|l|l|l|l|l|l|l|}
\hline Wyszczególnienie & CDS & REF & EMA & LID & IND & SOC & DEP & SPR & WSP & $\%$ \\
\hline $\begin{array}{l}\text { Studia wyższych } \\
\text { stopni }\end{array}$ & & & 1,181 & & & 0,893 & & & 1,085 & 41,2 \\
\hline Oferta kształcenia & 1,099 & 1,125 & 1,086 & & 1,140 & & & & & 35,3 \\
\hline Miejscowość & 1,156 & 1,146 & & & & & & & & 33,5 \\
\hline Baza dydaktyczna & & 1,091 & & 1,093 & & & & 1,138 & & 28,7 \\
\hline Potencjał kadrowy & 0,924 & 1,077 & & 1,093 & & & & 1,101 & & 28,2 \\
\hline Stypendium & & & & 1,147 & & & & & & 26,7 \\
\hline Czesne & 1,176 & & & & & 1,111 & 0,917 & & 0,913 & 26,2 \\
\hline Ranking & & & & 1,095 & & & & & & 26,0 \\
\hline Opinia znajomych & 1,175 & & & 1,157 & & 1,091 & & 1,101 & & 7,8 \\
\hline
\end{tabular}

${ }^{*}$ Regresja logistyczna ${ }^{4}$ - zmiennymi niezależnymi są czynniki. Tabela zawiera tylko statystycznie istotne na poziomie $\mathrm{p}<0,05$ współczynniki exp(b). Kolumna „\%” przedstawia procent osób uznających daną cechę oferty edukacyjnej lub uczelni za „bardzo ważną".

Zauważmy, że trzy pierwsze czynniki (CDS, REF, EMA) odnoszą się zasadniczo do problematyki perspektywy czasowej, refleksyjności decyzyjnej i autonomicznej orientacji na efekty. Czynnik CDS wyraźnie jest związany z preferencją miejsca studiów: wzrost czynnika CDS zwiększa o 15,6\% szanse wyboru studiów w Białymstoku. Carpe Diem Syndrome podnosi znaczenie „czesnego" (17,\%) i „opinii znajomych” $(17,5 \%)$ przy wyborze studiów. Mniejsze natomiast ma znaczenie „potencjał kadrowy”. Wydaje się, że w przypadku poczucia braku kontroli nad życiem, najlepszą postawą (strategią) jest zmniejszenie kosztów wejścia i wyjścia (ryzyka nieukończenia wyższych studiów, co może zagwarantować słabszy potencjał kadrowy i jego wymagania). Czynnik REF (refleksyjności decyzyjnej) koncentruje się na informacji związanej wyłącznie

4 Informacje dodatkowe w nocie metodologicznej „Regresja logistyczna”. 
z kwestiami edukacyjnymi, w tym z informacją o bazie dydaktycznej i potencjale kadrowym. Natomiast czynnik EMA (emocjonalna autonomia) wyłącznie wiąże się z kwestiami kształcenia jako źródle autonomicznych nagród. W tym przypadku znaczenie ma perspektywa kształcenia na studiach magisterskich (II stopnia) i doktorskich (III stopnia). Perspektywa osiągnięcia wyższych stopni kształcenia zwiększa się dla osób nastawionych na wewnętrzne motywacje (EMA 18,1\%) oraz posiadanie wsparcia społecznego (WSP 8,5\%). Osoby, które w procesie podejmowania decyzji korzystają z kontekstu społecznego (opinii grupy) przywiązują mniejszą rolę do możliwości kształcenia na wyższych stopniach. Osiąganie wysokiego poziomu wykształcenia (szczególnie na poziomie doktoratu) nie jest powszechnie przyjmowaną postawą wśród maturzystów, choć $41,2 \%$ maturzystów deklaruje, że jest to najważniejsze kryterium oceny oferty edukacyjnej. Ma ono rzeczywiście znaczenie dla osób, które wykształcenie traktują jako wartość autoteliczną (EMA) oraz mogą liczyć na wsparcie społeczne (WSP). Wydaje się, że dla większości maturzystów podkreślanie znaczenia perspektyw osiągnięcia wyższych stopni kształcenia jest w dużej mierze deklaratywne, rytualne. Efekt czynnika SOC, który oznacza odwoływanie się w decyzjach do opinii rówieśników, jest zgodny z tym przypuszczeniem. Osoby z dużym natężeniem SOC kierują się opinią funkcjonującą w grupie i efekt jest znaczący - spadek zainteresowania pespektywą uzyskania wyższych stopni edukacyjnych.

W kontekście wpływu społecznego na decyzje maturzystów na uwagę zasługuje „opinia znajomych”, której polisemiczność wyraźnie się ujawnia w relacji do różnych czynników. Można przyjąć, że osoby charakteryzujące się wysokim natężeniem czynnika CDS (utrata kontroli nad życiem) mogą opinię znajomych traktować jako instrukcję (podstawę strategii imitacyjnych). Dla czynnika REF (refleksyjności decyzyjnej) i EMA (autonomii emocjonalnej związanej z osiągnięciami) „opinia znajomych” nie ma znaczenia. Czynnik LID (orientacja na przywództwo) pozwala sądzić, że opinia znajomych (wzrost o 15,7\%) może w tym kontekście znaczyć uznanie ze strony innych. Tym bardziej, że LID jest jedynym czynnikiem, który ma istotny wpływ na uznawanie „rankingów” jako istotnej charakterystyki oferty edukacyjnej (uczelni, kierunku). „Opinia znajomych” w relacji do czynnika SOC (orientacja na kontekst społeczny) może być traktowana jako źródło informacji. Natomiast w kontekście czynnika SPR (sprawstwo) może wskazywać na kontekst współpracy lub inspiracji do działania. „Opinia znajomych” może więc funkcjonować jako instrukcja, nagroda, informacja i inspiracja. Nie ma znaczenia, gdy jednostka cechuje 
się wysoką refleksyjnością decyzyjną (REF), orientacją na efekt (EMA), gdy przejawia skłonność do indywidualizmu (IND), wykazuje duży stopień zależności od rodziców (DEP), jak również wsparcia $\mathrm{z}$ ich strony (WSP). „Opinia znajomych” odnosi się do komunikacji w grupie rówieśniczej i wiąże się z poczuciem kontroli, pozycją w grupie, wykorzystaniem zasobów wiedzy wspólnej oraz poczuciem sprawstwa.

Trafność wyróżnionych czynników potwierdza ich intuicyjny związek z oceną wagi „czesnego” jako kryterium znaczącego przy wyborze studiów. Maturzyści, którzy odczuwają wyższy poziom zależności od rodziców (ich oczekiwań i kontroli - DEP) oraz wyższy poziom wsparcia społecznego, w tym nepotyzmu rodzicielskiego (WSP) wykazują mniejsze zainteresowanie „czesnym”. Wydaje się, że jest to dość oczywisty związek: rodzicom zależy i stać ich na to, aby zapewnić studia dziecku, zapłacą więc czesne i maturzysta nie musi się tym martwić. To zmartwienie rodziców.

Informacja o dostępności wyższych poziomów kształcenia jest informacją trafiającą do szczególnego typu maturzystów. Miejscowość, w której znajduje się uczelnia, jest oczywistym parametrem związanym głównie $\mathrm{z}$ kosztami podjęcia studiów (kosztów migracji od innego miasta w Polsce). Informacja o bazie dydaktycznej, potencjale kadrowym jest informacją złożoną, trudną do weryfikacji. Jest ona istotna dla tych maturzystów, którzy podejmują decyzje refleksyjnie, ale również kierujących się na „przywództwo” LID (pojęcia „dydaktyka” i „kadra” odnoszą się do sfery późniejszych interakcji społecznych $\mathrm{w}$ relacji student-wykładowca) i sprawstwa SPR, czyli możliwości osiągnięcia sukcesu edukacyjnego dzięki indywidualnemu wysiłkowi. Przekazywana w reklamie edukacyjnej, promocjach, targach informacja o „ofercie kształcenia” na wyższych uczelniach ma jednak znaczenie podstawowe. Osoby bardziej skupione na teraźniejszości (SDS), podejmujące decyzję z większą rozwagą (REF), nastawione na efekty (EMA) oraz indywidualiści (IND) zwracają większą uwagę na ofertę kształcenia.

\section{Studia wyższe i szanse osiągania pożądanych celów}

Jeśli decyzja pójścia na studia ma charakter „inwestycyjny”, to maturzyści powinni postrzegać wykształcenie instrumentalnie jako środek zwiększający szanse osiągania cenionych przez siebie wartości (tabela 4).

W opinii maturzystów wyższe wykształcenie zwiększa przede wszystkim szanse na rozwój intelektualny $(83,1 \%)$, uzyskanie wysokich zarobków $(74,7 \%)$, realizację pracy pozwalającej realizować własne zainteresowania i pasje (68\%) oraz uzyskanie szacunku i uznania ze strony rodziców $(67,2 \%)$. 
Rozwój intelektualny, wysokie dochody i satysfakcjonująca praca związane są z osobistymi wartościami ucznia, mającymi znaczenie dla szans osiągnięcia wysokiej pozycji społecznej. Mimo tego, że młodzi ludzie znajdują się w „krytycznej” fazie cyklu życiowego, związanego głównie z poszerzaniem przestrzeni autonomii, to rodzice pozostają nadal ważnym punktem odniesienia w kształtowaniu poczucia własnej wartości, stanowiąc źródło szacunku i uznania.

Tabela 4. Pożądane cele i szanse ich osiągnięcia dzięki studiom (Model regresji logistycznej)

\begin{tabular}{|c|c|c|c|c|c|c|c|c|c|c|}
\hline $\begin{array}{l}\text { Zmienne } \\
\text { przewidywane } \\
\text { (zależne) }\end{array}$ & CDS & REF & EMA & LID & IND & SOC & DEP & SPR & WSP & $\%$ \\
\hline $\begin{array}{l}\text { Rozwoju intelektual- } \\
\text { nego }\end{array}$ & 0,735 & 1,218 & 1,612 & & & 1,165 & & & 1,266 & 83,1 \\
\hline $\begin{array}{l}\text { Uzyskania wysokich } \\
\text { zarobków }\end{array}$ & 0,913 & & 1,147 & & & 1,122 & 1,110 & & & 74,7 \\
\hline $\begin{array}{l}\text { Uzyskania pracy po- } \\
\text { zwalającej zrealizować } \\
\text { własne zainteresowa- } \\
\text { nia i pasje }\end{array}$ & 0,762 & 1,180 & 1,181 & & & & & 1,140 & 1,133 & 68,0 \\
\hline $\begin{array}{l}\text { Uzyskania szacunku } \\
\text { i uznania ze strony } \\
\text { rodziców }\end{array}$ & & 1,110 & 1,289 & 1,242 & & 1,112 & 1,425 & & 1,170 & 67,2 \\
\hline $\begin{array}{l}\text { Uzyskania praktycznej } \\
\text { wiedzy potrzebnej do } \\
\text { wykonywania pracy } \\
\text { zawodowej }\end{array}$ & 0,902 & 1,152 & 1,180 & & & 1,089 & & 1,128 & 1,132 & 64,3 \\
\hline $\begin{array}{l}\text { Uzyskania dobrej } \\
\text { pracy za granicą }\end{array}$ & & & 1,099 & & & & 1,147 & & 1,104 & 63,6 \\
\hline $\begin{array}{l}\text { Znalezienia wymarzo- } \\
\text { nej pracy }\end{array}$ & 0,761 & & 1,085 & & & & & 1,091 & 1,130 & 62,3 \\
\hline $\begin{array}{l}\text { Uczestnictwa i dostę- } \\
\text { pu do kultury }\end{array}$ & 0,857 & 1,174 & 1,265 & 1,140 & & 1,190 & 0,922 & 1,083 & 1,169 & 52,7 \\
\hline Uniknięcia bezrobocia & 0,862 & & 1,086 & 1,098 & & 1,131 & & 1,127 & 1,086 & 47,5 \\
\hline $\begin{array}{l}\text { Uzyskania szacunku } \\
\text { i uznania ze strony } \\
\text { koleżanek i kolegów }\end{array}$ & & & 1,181 & 1,150 & & 1,142 & 1,090 & & & 43,0 \\
\hline $\begin{array}{l}\text { Znalezienia atrakcyj- } \\
\text { nego partnera życio- } \\
\text { wego }\end{array}$ & & & & 1,336 & & 1,233 & 1,118 & 1,098 & & 27,3 \\
\hline Wpływania na innych & & & & 1,158 & & & 1,103 & & & 24,6 \\
\hline
\end{tabular}

Regresja logistyczna - zmiennymi niezależnymi są czynniki. Tabela zawiera tylko statystycznie istotne na poziomie $\mathrm{p}<0,05$ współczynniki exp(b). Kolumna „\%” zawiera procent osób uznających, że ukończenie studiów zwiększa w stopniu dużym i bardzo dużym szanse osiągnięcia danego celu. 
Wykształcenie wyższe ma jednak odmienne znaczenie dla uczniów różniących się postawami (profilem czynnikowym). Wysoki poziom poczucia utraty kontroli nad życiem (ze względu na rolę przypadku lub fatalizm), życie chwilą obecną, nieumiejętność planowania i niezdolność wyobrażenia sobie sytuacji życiowej w przyszłości - czyli syndrom Carpe Diem Syndrome - skutkuje znaczącym pogorszeniem wiary w prawie wszystkie pozytywne efekty wykształcenia, w szczególności szanse rozwoju intelektualnego (-26\%) i uzyskanie wymarzonej pracy (-24\%), pozwalającej realizować zainteresowania i pasje (-24\%). Podjęcie studiów, uzyskanie wyższego wykształcenia jest natomiast niezwykle znaczące dla osób autonomicznych emocjonalnie, dla których osiąganie celów jest zasadniczym źródłem satysfakcji (EMA). Przede wszystkim oczekują one znaczącego zwiększenia szans rozwoju intelektualnego $(61,2 \%)$, uzyskania szacunku ze strony rodziców $(28,9 \%)$, dostępu i uczestnictwa w kulturze (26,5\%). Są to wartości, na które zwracają uwagę również osoby refleksyjnie podejmujące decyzje (REF). Warto podkreślić, że w postawie związanej z EMA istotne znaczenie mają szanse na uzyskanie wysokich zarobków $(18,1 \%)$, uzyskanie dobrej pracy za granicą $(9,9 \%)$, znalezienia wymarzonej pracy $(8,5 \%)$, uniknięcia ryzyka bezrobocia $(8,6 \%)$ oraz uzyskanie szacunku i uznania ze strony koleżanek i kolegów $(18,1 \%)$. O ile postawa REF i EMA nie różnią się w ogólnej percepcji wykształcenia jako czynnika związanego z rozwojem intelektualnym i uczestnictwem w kulturze, o tyle EMA - związana $\mathrm{z}$ osiąganiem satysfakcji z osiągania celów - specyficznie akcentuje utylitarny charakter pracy (płace i uniknięcie bezrobocia) oraz jej prestiżowy charakter (uznanie znajomych). Wydaje się, że w warunkach współczesnego rynku pracy orientacja na wewnętrzne źródło nagród (kar) jest postawą mającą większy wpływ na kształtowanie motywacji osiągnięć.

W przeciwieństwie do czynników związanych z perspektywą czasową i refleksyjnością procesów decyzyjnych (CDS, REF, EMA), czynniki odnoszące się do wymiarów interakcji społecznych (SOC, DEP, SPR, WSP) mają $z$ reguły pozytywny wpływ na postrzeganie roli wykształcenia. Potwierdzaja również trafność wyróżnionych postaw. Zauważmy, że uzyskanie „szacunku i uznania ze strony rodziców" dzięki podjęciu studiów jest silnie związane z czynnikiem DEP (oczekiwaniami i kontrolą ze strony rodziców). Wysokie wartości czynnika DEP podnoszą o $42,5 \%$ szanse na wskazania szacunku i uznania ze strony rodziców, przy jednoczesnym obniżeniu szans na uzyskanie dostępu i uczestnictwa w kulturze $(-8,2 \%)$ i postrzeganiu wykształcenia jako środka „wpływania na innych” (10,3\%). Wydaje się to zrozumiałe, jeśli oczekiwania i kontrola ze strony rodziców oraz uzyskiwane z ich strony 
uznanie i szacunek prowadzą do podejmowania decyzji edukacyjnych zgodnych $\mathrm{z}$ ambicjami rodziców, ale nie całkiem odpowiadających zainteresowaniom uczniów. W szczególności, gdy maturzyści mają zainteresowania humanistyczne, ale pod wpływem oczekiwań i nacisków rodziców nie podejmują studiów na kierunkach humanistycznych, mogą odczuwać to jako ograniczenie dostępu do kultury. Konformizm jest w tym przypadku źródłem znaczących nagród społecznych, ale może być również źródłem dyskomfortu. A spełnienie oczekiwań innych osób może być postrzegane również jako szansa wpływania na relacje $\mathrm{z}$ nimi.

Orientacja na przywództwo w grupie (LID) potwierdza trafność wyróżnienia tej postawy. Nie ma ona związku z żadnymi istotnymi charakterystykami wykształcenia wyższego związanymi z rozwojem intelektualnym, szansami na uzyskanie atrakcyjnej i dochodowej pracy. Natomiast znacząco wzrastają szanse na uzyskanie szacunku i uznania ze strony rodziców $(24,2 \%)$, koleżanek i kolegów (15\%), uczestnictwa w kulturze (14\%) oraz wpływania na innych $(15,8 \%)$. Wykształcenie wyższe jest postrzegane jako czynnik statusu społecznego związanego z uznaniem i szacunkiem, uczestnictwem w kulturze, wywieraniem wpływu społecznego. Wydaje się, że w trójwymiarowej koncepcji czynników statusu (bogactwo-władza-prestiż), czynnik LID - na poziomie mikrostrukturalnym - identyfikuje osoby zorientowane na „władzę i prestiż”, wywieranie wpływu za pomocą uzyskanego szacunku i uznania (respektu).

Z postawą LID - związaną funkcjonalnie z pozycją statusową - wiąże się również postrzeganie wykształcenia (podjęcia studiów) jako czynnika zwiększającego szanse na znalezienie atrakcyjnego partnera życiowego $(33,6 \%)$. Studia to okres „doboru partnerskiego” - formowanie się trwałych związków partnerskich (również małżeńskich). Cechy składające się na postawę LID są dobrymi predyktorami powodzenia w przyszłości, szans zajęcia wysokiej pozycji społecznej w skali makrospołecznej. Znalezienie atrakcyjnego partnera życiowego dzięki podjęciu studiów jest również związane $\mathrm{z}$ nastawieniem na kontekst społeczny (SOC) w procesie decyzyjnym $(23,3 \%)$, poczuciem zależności (DEP) od rodziców (11,8\%) oraz sprawstwa (SPR), przekonania, że od indywidualnego wysiłku i ambicji zależy sukces w życiu (9,8\%). We współczesnym społeczeństwie dobór partnerski nie jest procesem losowym, a wykształcenie jest jednym z podstawowych wymiarów „doboru asortatywnego”, hipergamii, dziedziczenia pozycji społecznej (ruchliwości międzygeneracyjnej). Rodzice maturzystów stanowią dla nich ważne źródło informacji o regułach reprodukcji struktury społecznej. Rodziców posiadających taki sam poziom wykształcenia ma 54\% maturzystów. 
Ojca lepiej wykształconego od matki ma 32\% uczniów, zaś odwrotnie - tylko $14 \%$. Poziom wykształcenia rodziców jest skorelowany $(\mathrm{r}=0,54)$, przy czym występuje nadal sytuacja przewagi związków, w których mężczyzna ma wyższy poziom wykształcenia. Wykształcenie ma również wpływ na szanse odziedziczenia statusu. Maturzyści, którzy mają rodziców legitymujących się wykształceniem podstawowym rzadziej planują kontynuację nauki na wyższej uczelni (70,2\% dla ojców z wykształceniem podstawowym i 67,7\% dla matek). Wraz ze wzrostem poziomu wykształcenia zwiększa się odsetek deklaracji kontynuowania studiów. I dla ojców z wykształceniem wyższym osiąga on poziom $83 \%$, dla matek $79,8 \%$. Zauważyć można, że ojcowie o wykształceniu podstawowym i wyższym wywierają większy wpływ na chęć kontynuacji nauki - być może dla jednych wykształcenie wyższe jest szansą na podwyższenie (w perspektywie międzygeneracyjnej) statusu społecznego, dla drugich - czynnikiem osłabiającym ryzyko obniżenia statusu.

Na koniec warto podkreślić paradoksalny efekt postawy indywidualistycznej (IND). O ile czynniki związane z procesem decyzyjnym (CDS, REF, EMA) lub kontekstem społecznym (LID, SOC, DEP, SPR, WSP) kształtują postrzeganie decyzji podjęcia studiów wyższych jako środka różnicującego szanse uzyskiwania różnych atrakcyjnych celów życiowych (rozwój intelektualny, praca, szacunek społeczny, związki partnerskie), o tyle postawa indywidualistyczna (IND) nie ma żadnego wpływu na wymienione cele, wartości. Postawa wyrażająca się tym, że w dążeniu do sukcesu jednostka musi liczyć tylko na siebie (nie może liczyć na innych), musi opierać decyzje na własnych przekonaniach, a nie na „dobrych radach”, być nieufna, ostrożna i nie powinna mieć pretensji do innych za swe porażki, nietrafne decyzje - nie wpływa na postrzeganie wykształcenia (podjęcia studiów wyższych). To, czy się jest skrajnym indywidualistą czy przeciwnie - liczy się na pomoc, ufa innym, korzysta $z$ ich „,dobrych rad”, a przyczyny porażek lokuje się w kontekście zewnętrznym lub obwinia za nie innych nie ma znaczenia w kontekście decyzji edukacyjnych. Niezależnie od tego, czym jest postawa IND, jest ona wyraźnie różna od czynnika CDS, który zdecydowanie deprecjonuje wartość wykształcenia (studiowania), a więc - z uwagi na krótki horyzont czasowy decyzji - nie postrzega wykształcenia w kategoriach „inwestycyjnych”, dla których jest niezbędna dłuższa perspektywa czasowa, cierpliwość w oczekiwaniu na planowane, przewidywanie korzyści. 


\section{Wykształcenie w kontekście uwarunkowań realizacji planów życiowych}

Plany życiowe nie muszą być związane wyłącznie z osiągnięciem wysokiego poziomu wykształcenia oraz ograniczać się tylko do tego, co dzięki wykształceniu można osiągnąć w sferze osobistej i zawodowej. Realizacja planów życiowych może zależeć od poziomu uzyskanego wykształcenia, ale również inne czynniki mogą wpływać na szanse ich realizacji.

Tabela 5. Uwarunkowania szans realizacji planów życiowych (Model regresji logistycznej)

\begin{tabular}{|c|c|c|c|c|c|c|c|c|c|c|}
\hline Wyszczególnienie & CDS & REF & EMA & LID & IND & SOC & DEP & SPR & WSP & $\%$ \\
\hline $\begin{array}{l}\text { Znajomość języków } \\
\text { obcych }\end{array}$ & & 1,096 & 1,336 & & 1,116 & & & 0,882 & 1,144 & 58,9 \\
\hline $\begin{array}{l}\text { Własna praca (praco- } \\
\text { witość) }\end{array}$ & 0,757 & 1,346 & 1,661 & & & & 0,902 & & & 54,6 \\
\hline $\begin{array}{l}\text { Talent, własne zdol- } \\
\text { ności }\end{array}$ & 0,869 & 1,264 & 1,639 & 1,128 & 1,147 & 0,892 & 0,923 & & 1,106 & 53,2 \\
\hline $\begin{array}{l}\text { Zapotrzebowanie na } \\
\text { zawód, który będziesz } \\
\text { wykonywał(a) }\end{array}$ & 1,106 & 1,150 & 1,500 & 0,809 & & & & 0,919 & & 50,7 \\
\hline Szczęście & 1,326 & & 1,266 & & 1,111 & 0,901 & & 0,857 & 1,089 & 47,7 \\
\hline $\begin{array}{l}\text { Kontakty, znajomości } \\
\text { z wysoko postawiony- } \\
\text { mi osobami }\end{array}$ & 1,235 & 1,093 & 1,208 & 1,148 & 1,157 & & & 0,776 & & 47,6 \\
\hline Spryt & 1,176 & 1,204 & 1,366 & 1,229 & 1,171 & 0,919 & & 0,922 & & 46,4 \\
\hline Własne wykształcenie & & & & & & 1,151 & & 1,096 & 1,156 & 39,7 \\
\hline Wdzięk, urok osobisty & 1,328 & & 1,199 & 1,246 & 1,302 & 0,868 & 0,891 & & 1,107 & 26,4 \\
\hline Kondycja gospodarki & 1,150 & 1,228 & 1,315 & & 1,116 & & & & 1,200 & 21,8 \\
\hline $\begin{array}{l}\text { Pochodzenie } \mathrm{z} \text { bogatej } \\
\text { rodziny }\end{array}$ & 1,427 & & & 1,112 & 1,213 & & 1,144 & 0,794 & & 18,7 \\
\hline $\begin{array}{l}\text { Obecność Polski } \\
\text { w organizacjach } \\
\text { międzynarodowych, } \\
\text { takich jak Unia Euro- } \\
\text { pejska }\end{array}$ & 1,190 & 1,255 & 1,268 & 1,241 & 1,143 & & 1,111 & 1,212 & 1,186 & 15,4 \\
\hline Miejsce zamieszkania & 1,217 & 1,248 & 1,232 & 1,118 & 1,359 & & & & & 14,7 \\
\hline $\begin{array}{l}\text { Dobrze wykształceni } \\
\text { rodzice }\end{array}$ & 1,287 & 1,252 & & 1,232 & 1,195 & & 1,166 & & 1,243 & 11,1 \\
\hline Politycy & 1,276 & 1,310 & & 1,190 & & & & 1,190 & & 8,7 \\
\hline
\end{tabular}

Regresja logistyczna - zmiennymi niezależnymi są czynniki. Tabela zawiera tylko statystycznie istotne na poziomie $\mathrm{p}<0,05$ współczynniki exp(b). Kolumna „\%” zawiera procent osób uznających, że dany aspekt, warunek może odegrać „Bardzo ważną rolę” w realizacji planów życiowych. 
Nie jest zaskoczeniem, że postawa CDS znacznie deprecjonuje znaczenie własnej pracy (pracowitości) oraz talentu i zdolności. W świecie, w którym trudno mieć kontrolę nad zdarzeniami, w którym rządzi przypadek lub konieczność (fatum), własna praca i talent nie mają większego znaczenia. Liczyć się może szczęście $(32,6 \%)$, wdzięk i urok osobisty $(32,8 \%)$, spryt $(17,6 \%)$ oraz szanse wynikające ze statusu przypisanego (odziedziczonego): pochodzenie z bogatej rodziny $(42,7 \%)$, dobrze wykształceni rodzice $(28,7 \%)$. Wydaje się, że postawa Carpe Diem Syndrome jest nie tylko konsekwencją poczucia utraty kontroli nad zdarzeniami, ale również efektem tego, że postrzega się świat społeczny w kategoriach trudnych do pokonania determinant statusowych (strukturalnych) i osobistych zdolności do wykorzystywania nadarzających się okazji (szczęście, wdzięk, spryt). Carpe Diem Syndrome jest strategią przystosowawczą do świata, w którym liczą się względnie sztywne podziały statusowe, a jednostka może przystosować się do tego świata wyłącznie przez poszukiwanie szczęśliwych i unikanie przykrych zdarzeń, sytuacji.

W przeciwieństwie do CDS refleksyjne podejmowanie decyzji (REF) i emocjonalna autonomii zorientowana na efekty (EMA) wyraźnie podkreślają pozytywną rolę własnej pracy (pracowitości) i talentu, własnych zdolności. O ile CDS - przypomnę - warunkował deprecjację studiów jako środka rozwoju, uzyskania atrakcyjnej i dobrze płatnej pracy, szacunku, o tyle REF i EMA podkreślały znaczenie wykształcenia wyższego (tabela 4). Pracowitość i talent mają zdecydowane większe znaczenie dla osób zorientowanych na efekty niż dla tych, którzy jedynie podejmują decyzje refleksyjnie. Emocjonalna autonomia podnosi szanse realizacji planów życiowych dzięki własnej pracy o 66\% (REF o 35\%), a dzięki talentowi i zdolnościom o 64\% (REF o 26\%). W przypadku REF i EMA nie ma znaczenia pochodzenie $\mathrm{z}$ bogatej rodziny (niezwykle istotny czynnik sukcesu życiowego dla postawy CDS).

„Własne wykształcenie” nie ma znaczenia jako czynnik sukcesu dla osób, które raczej postrzegają sukces jako konsekwencję własnych działań (CDS, REF, EMA, LID), ma natomiast dla osób, które w procesie decyzyjnym kładą nacisk na kontekst społeczny (SOC i WSP) oraz sprawstwo. Można sądzić, że „własne wykształcenie” jako czynnik pomocny przy realizacji planów życiowych funkcjonuje jedynie jako cecha klasyfikacyjna, gdyż sukces zależy nie tyle od tego, jakie się ma wykształcenie, ale jaki się zrobi z niego użytek, dzięki pracowitości i talentowi. Podkreślić warto, że czynniki związane z procesem podejmowania decyzji (CDS, REF, EMA i LID) również podkreślają informacje o popycie na wykonywany zawód (jest to szczególnie 
istotne dla EMA - zwiększa szanse wyboru o 50\%). Kondycja gospodarki (dla EMA 31,5\%), kontakty, znajomości z wysoko postawionymi osobami („kapitał społeczny”) - zwiększają szanse zarówno dla CDS i EMA. Podkreślić warto, że dla maturzystów (z lat 2010-2015) kontekst instytucjonalny związany z obecnością Polski w organizacjach międzynarodowych, takich jak Unia Europejska, miał znaczenie dla wszystkich czynników, z wyjątkiem SOC, który wiąże się z orientacją na kontekst decyzyjny w skali mikrospołecznej grupy rówieśniczej.

Postawa indywidualistyczna (IND), która nie miała znaczenia w kontekście decyzji o podjęciu studiów, w szerszym kontekście szans warunkujących realizację "planów życiowych" staje się aktywna. W zasadzie ma wzorzec identyfikacji szans podobny do CDS, z wyjątkiem postrzegania talentu, własnych zdolności oraz roli polityków. W postawie CDS talent tracił na znaczeniu, dla indywidualistów jest znaczący. W postawie CDS politycy odgrywają znaczącą rolę (być może w świecie trudnym do kontroli na polityków delegowana jest zdolność kontroli procesów społecznych), podczas gdy dla indywidualistów politycy nie mają znaczenia jako czynnik odgrywający ważną rolę w realizacji planów życiowych. Wydaje się, że postawa indywidualistyczna przypomina postawę CDS, ale jest związana $\mathrm{z}$ orientacją na realizację wartości niezwiązanych z edukacją formalną, zaś profil psychologiczny związany z nieufnością i poleganiem jedynie na własnych siłach może być efektem nieprzystosowania do wymagań dyscypliny systemu szkolnego.

\section{Postrzeganie roli szkoły w kształtowaniu postaw i decyzji edukacyjnych}

Wyróżnione czynniki charakteryzujące postawy maturzystów nie tworzą homogenicznej klasy. Czynniki CDS, REF, EMA i LID mogą odzwierciedlać względnie trwałe zróżnicowania indywidualne o charakterze psychologicznym w dużym stopniu uwarunkowane predyspozycjami genetycznymi (poziomem IQ, temperamentem). Z drugiej strony środowisko rodzinne stanowi wysoce zróżnicowane źródło specyficznych uwarunkowań socjalizacyjnych związanych z poziomem wykształcenia rodziców, dostępnymi zasobami materialnymi, wartościami i stylem życia, aspiracjami związanymi z dziećmi, kontrolą ich zachowania. O ile czynniki „genetyczne” mogły mieć znaczenie we wczesnych fazach życia (również związane z płcią), o tyle późniejsza socjalizacja w rodzinie mogła wprowadzić znaczące modyfikacje przez interakcje środowiskowe. Na kolejnym etapie kształtowania 
postaw pojawia się szkoła. W szkole proces socjalizacyjny jest uwarunkowany oddziaływaniami grupy rówieśniczej oraz kadry nauczycielskiej. Trudno ocenić stopień trwałości ukształtowanych postaw we wcześniejszych fazach życia i w rezultacie nie jest łatwo ocenić, na ile osiągnięcia szkolne są uwarunkowane trwałymi dyspozycjami ucznia, na ile zaś dyspozycje te są kształtowane przez szkołę - osiągnięcia edukacyjne ucznia, interakcje z nauczycielami i grupą rówieśniczą. Wydaje się, że podstawowe kompetencje społeczne związane $\mathrm{z}$ funkcjonowaniem $\mathrm{w}$ grupie ukształtowały się znacznie wcześniej, na etapie przedszkolnym lub w szkole podstawowej. W szkole średniej - szczególnie w kontekście kształtowania postaw związanych z podjęciem studiów - decydującą rolę mogą odgrywać nauczyciele.

Tabela 6. Postrzeganie szkoły w kształtowaniu postaw (Model regresji logistycznej)

\begin{tabular}{|c|c|c|c|c|c|c|c|c|c|c|}
\hline $\begin{array}{l}\text { Zmienne } \\
\text { przewidywane } \\
\text { (zależne) }\end{array}$ & CDS & REF & EMA & LID & IND & SOC & DEP & SPR & WSP & $\%$ \\
\hline $\begin{array}{l}\text { Moja szkoła dobrze } \\
\text { przygotowała mnie do } \\
\text { dalszego życia }\end{array}$ & 0,897 & 1,145 & & 1,038 & 0,857 & 1,138 & & 1,282 & 1,174 & 38,1 \\
\hline $\begin{array}{l}\text { Poleciłbym moją } \\
\text { szkołę młodszemu } \\
\text { rodzeństwu }\end{array}$ & & & & & & & & 1,125 & 1,144 & 37,1 \\
\hline $\begin{array}{l}\text { Uczeń, który jeszcze } \\
\text { nie wie, co będzie } \\
\text { robił po maturze, } \\
\text { może liczyć na poradę } \\
\text { nauczycieli }\end{array}$ & & 1,156 & & 1,118 & 0,916 & 1,112 & & 1,123 & 1,208 & 33,6 \\
\hline $\begin{array}{l}\text { Szkoła nie robi nic, } \\
\text { aby pomóc uczniom } \\
\text { w wyborze kariery po } \\
\text { maturze }\end{array}$ & & & 1,103 & & 1,181 & & & & 0,863 & 29,2 \\
\hline $\begin{array}{l}\text { Nauczyciele rozma- } \\
\text { wiają z uczniami na } \\
\text { temat najbardziej } \\
\text { przyszłościowych } \\
\text { zawodów }\end{array}$ & 1,104 & 1,180 & & 1,147 & 0,906 & & & 1,242 & 1,235 & 24,1 \\
\hline $\begin{array}{l}\text { Nauczyciele w mojej } \\
\text { szkole często rozma- } \\
\text { wiają z uczniami o ich } \\
\text { przyszłości }\end{array}$ & & 1,200 & & 1,198 & 0,910 & & & 1,277 & 1,219 & 23,0 \\
\hline
\end{tabular}

Regresja logistyczna - zmiennymi niezależnymi są czynniki. Tabela zawiera tylko statystycznie istotne na poziomie p $<0,05$ współczynniki $\operatorname{EXP}(\mathrm{B})$. „\%” - procent osób akceptujących opinię o własnej szkole i nauczycielach. 
Osoby przyjmujące postawę refleksyjną w podejmowaniu decyzji (REF) z reguły lepiej oceniają własną szkołę, podkreślając, że szkoła dobrze przygotowała je do dalszego życia (14,5\%), nauczyciele udzielali porad (15,6\%), przekazywali informacje o przyszłościowych zawodach (18\%) i rozmawiali z uczniami o ich przyszłości (20\%). Jest rzeczą interesującą, że uczniowie refleksyjni podobnie oceniają szkołę jak uczniowie charakteryzujący się orientacją na przywództwo w grupie (LID). Nasuwa się przypuszczenie, że nauczyciele chętnie rozmawiają z uczniami, którzy sami wykazują wysoką potrzebę pozyskiwania informacji, aby refleksyjnie podejmować decyzje edukacyjne, oraz wyróżniają się na tle innych aktywnością i kompetencjami komunikacyjnymi. Krytycznie oceniają szkołę uczniowie prezentujący postawę CDS oraz uczniowie zorientowani na efekty - uczniowie emocjonalnie autonomiczni (EMA) częściej akceptują opinię, że szkoła nie robi nic, aby pomóc uczniom w wyborze kariery po maturze. Szkoła jest niewątpliwie miejscem kształtowania poczucia sprawstwa. Osoby przekonane, że w życiu znaczenie ma indywidualny wysiłek i ambicja, którzy w decyzjach wykazują się asertywnością (SPR) oraz mają świadomość wsparcia ze strony osób zaufanych i rodziców (WSP) z reguły pozytywnie oceniają szkołę, działania nauczycieli.

Szczególnie krytyczny, negatywny stosunek do szkoły przejawiają osoby o postawach indywidualistycznych (IND). Najgorzej oceniają szkołę ze względu na przygotowanie ucznia do dalszego życia. Uczeń, który nie wie, co będzie robił w przyszłości, nie otrzymuje od nauczyciela porady, gdyż szkoła nie pomaga uczniom w wyborze kariery po maturze i nauczyciele nie rozmawiają z uczniami o przyszłościowych zawodach i o ich osobistych perspektywach. Postawa indywidualistyczna - nieufność, liczenie na siebie, niechęć do przyjmowania „dobrych rad” - może być przeszkodą w nawiązaniu komunikacji z nauczycielami. Wydaje się, że postawa IND związana jest $\mathrm{z}$ odniesieniem do wartości niezwiązanych specyficznie z systemem nauczania. Może się w niej ujawniać trudności adaptacyjne lub skłonność do zachowań anty-społecznych (dewiacyjnych w sensie Mertona).

\section{Socjologiczne determinanty postaw}

Socjologowie nieufnie podchodzą do wyjaśnień w kategoriach „psychologicznych" - postaw, stylów poznawczych, orientacji - podejrzewając, że są one "korelatami” uwarunkowań społecznych związanych pełnioną rolą społeczną, cechami demograficznymi (płeć, wiek), środowiskiem (miejsce zamieszkania). Maturzyści stanowią homogeniczną wiekowo kategorię, 
a więc nie występują czynniki związane ze zróżnicowaniem cyklu życiowego, doświadczeniem pokoleniowym. Większość (75\% maturzystów) mieszka w Białymstoku, pozostali w gminach ościennych. W porównaniu z populacją generalną wyższy jest przeciętny poziom wykształcenia rodziców i mniejsze jest zróżnicowanie. Znacznie częściej rodzicie prowadzą własną działalność gospodarczą - w próbach losowych z populacji ogólnej znajduje się około5-6\% badanych prowadzących własną działalność gospodarczą . Wśród maturzystów Białegostoku w latach 2010-2015 odsetek rodziców prowadzących działalność gospodarczą wyniósł 35\%.

Tabela 7. Socjologiczne uwarunkowania postaw. (Model regresji liniowej)

\begin{tabular}{|c|c|c|c|c|c|c|c|c|c|}
\hline $\begin{array}{l}\text { Zmienne } \\
\text { niezależne }\end{array}$ & LID & WSP & EMA & DEP & CDS & SPR & SOC & IND & REF \\
\hline $\begin{array}{l}\text { Płeć (1 - kobiety, } \\
\text { o - mężczyźni) }\end{array}$ & $-0,151$ & 0,076 & 0,119 & $-0,076$ & & $-0,067$ & & & \\
\hline $\begin{array}{l}\text { Wykształcenie ojca } \\
\text { (lata nauki) }\end{array}$ & & & 0,204 & & & & & & \\
\hline $\begin{array}{l}\text { Wykształcenie } \\
\text { matki (lata nauki) }\end{array}$ & & & 0,211 & & & & & & \\
\hline $\begin{array}{l}\text { Wykształcenie } \\
\text { łączne }\end{array}$ & 0,176 & & $-0,339$ & & & 0,295 & & & \\
\hline $\begin{array}{l}\text { Położenie mate- } \\
\text { rialne }^{* *}\end{array}$ & & 0,110 & & 0,089 & $-0,062$ & & $-0,049$ & & \\
\hline $\begin{array}{l}\text { Miejsce } \\
\text { zamieszkania (1 - } \\
\text { Białystok, o - inne } \\
\text { miasta i wieś) }\end{array}$ & & & & & & & & $-0,046$ & 0,041 \\
\hline $\begin{array}{l}\text { Działalność } \\
\text { gospodarcza }^{* * *}\end{array}$ & 0,049 & & & & $-0,052$ & & & & $-0,045$ \\
\hline \multicolumn{10}{|l|}{ Typ szkoły: liceum } \\
\hline \multicolumn{10}{|l|}{$\begin{array}{l}\text { Typ szkoły: } \\
\text { technikum }\end{array}$} \\
\hline $\begin{array}{l}\text { Kursy } \\
\text { dokształcające } \\
\end{array}$ & & & & 0,056 & & & & $-0,058$ & \\
\hline R-kwadrat & 0,035 & 0,026 & 0,021 & 0,020 & 0,015 & 0,013 & 0,013 & 0,009 & 0,008 \\
\hline
\end{tabular}

Regresja liniowa (wielokrotna) - zmiennymi zależnymi są czynniki. Tabela zawiera tylko statystycznie istotne na poziomie $\mathrm{p}<0,05$ standaryzowane współczynniki beta. Można je porównywać pod względem „siły wpływu” na zmienne zależne (czynniki)

${ }^{*}$ Iloczyn lat nauki matki i ojca.

** Subiektywna ocena: 1 - dochód rodziny ucznia wyższy od przeciętnego, 0 - nie gorszy od przeciętnego

*** Rodzice mają własną firmę

**** Liczba płatnych zajęć dodatkowych organizowanych poza szkołą

5 Informacja z Aneksu Komunikatu 54/2017 CBOS. Nie wszystkie komunikaty posiadają Aneks „metryczkowy". 
Przyjęty model pokazuje, że wyróżnione czynniki są słabo „zdeterminowane” przez typowe zmienne „socjologiczne”. Uwarunkowania społeczne najsilniej determinują orientację na przywództwo (LID). Jest ona silniejsza wśród chłopców niż dziewcząt oraz wśród uczniów, których rodzice prowadzą działalność gospodarczą. Wynik odzwierciedla z jednej strony stereotypowe oczekiwania kulturowe związane $\mathrm{z}$ płcią, z drugiej - przekaz wzorca aktywności związanego z postawą „przedsiębiorcy”, który musi posiadać kompetencję zarządzania zespołami pracowniczymi. Wykształcenie rodziców nie ma wpływu na kształtowanie się postawy LID, ale gdy uwzględni się łącznie wykształcenie ojca i matki, to ujawnia się synergiczny efekt wykształcenia. Podobny efekt występuje również w przypadku kształtowania się poczucia sprawstwa (SPR). Być może zrównoważony poziom wykształcenia, podobieństwo sprawności komunikacyjnej i zainteresowań stwarza lepsze środowisko do kształtowania się postaw asertywnych. I w tym przypadku ujawnia się tradycyjny wzór socjalizacyjny, którego efektem jest wyższe poczucie sprawstwa (SPR) wśród chłopców. Podobne - typowe - zależności widać w przypadku czynnika refleksyjności, charakteryzującego uczniów mieszkających w mieście, których rodzice nie prowadzą działalności gospodarczej. Indywidualizm charakteryzuje istotnie silniej uczniów spoza Białegostoku, z gmin wiejskich - w tym kontekście nieufność i liczenie wyłącznie na własne siły oraz krytyczna ocena szkoły w kształtowaniu postaw związanych z podjęciem studiów mogą po prostu odzwierciedlać trudności $\mathrm{z}$ adaptacją do życia w środowisku wielkomiejskim, reguł instytucjonalnych i wiązania planów na życie $\mathrm{z}$ aktywnością niewiążącą się silnie z poziomem i profilem osiągniętego wykształcenia. Spośród wyróżnionych czynników interesująco przedstawia się postawa zorientowana na efekt - autonomia emocjonalna (EMA). Jak widać, osiąganie satysfakcji z realizacji dokładnie zaplanowanych efektów oraz odczuwanie złości na siebie w przypadku niepowodzenia charakteryzuje częściej dziewczęta. Niewykluczone, że $\mathrm{w}$ tradycyjnym stereotypie płci, w którym to chłopcy cechują się większymi predyspozycjami do przyjmowania ról dominujących (LID), związanych z zewnętrznymi nagrodami (uznanie), mieści się również to, że dziewczęta są socjalizowane do tego, aby osiągać większą satysfakcję z realizacji dobrze zaplanowanych przedsięwzięć (EMA). Zagadkową rolę w kształtowaniu się postawy EMA odgrywa wykształcenie rodziców. Wyższy poziom wykształcenia zarówno ojca i matki mają wpływ pozytywny, ale łącznie indukują negatywną interakcję. Słowem, gdy oboje rodziców mają wyższy poziom wykształcenia, to dziecko w słabszym stopniu wykształca w sobie postawę autonomii emocjonalnej. Na uwagę również zasługuje fakt, że to chłopcy 
w większym stopniu charakteryzują się poczuciem uzależnienia od rodziców - podkreślają, że rodzice mają wobec nich oczekiwania i starają się nadmiernie kontrolować ich życie (DEP). Dotyczy to w większym stopniu osób, które uważają, że znajdują się w lepszym położeniu materialnym niż ich rówieśnicy. Na pierwszy rzut oka wydaje się to niezgodne ze stereotypem większej troski i kontroli rodziców nad zachowaniem dziewcząt. Wydaje się jednak, że stwierdzona zależność jest raczej pochodną ostrzejszych napięć i konfliktów między dorastającymi chłopcami dążącymi do zwiększenia autonomii a rodzicami usiłującymi wpływać dyscyplinująco na niepożądane zachowania chłopców (np. w zakresie rozrywki, manier grzecznościowych, ryzyko sięgnięcia po alkohol, dopalacze).

Typ szkoły (liceum lub technikum) nie ma znaczenia w kształtowaniu się postaw. Jedynie uczestnictwo w kursach dokształcających organizowanych w szkołach i często odpłatnych ma związek z poczuciem zależności od rodziców (DEP), którzy wywierają nacisk na dokształcanie i za nie płacą, oraz $\mathrm{z}$ indywidualizmem (IND), czynnikiem wyrażającym negatywną postawę wobec szkoły i nauczycieli.

\section{Zakończenie}

Trzy ogólne wnioski wyłaniają się z przedstawionych wyników. Po pierwsze, wyraźne zaznaczają się dwa odrębne wymiary decyzji - wymiar preferencji indywidualnych związanych perspektywą czasową, refleksyjnością, orientacją na rezultat, sprawstwem oraz wymiar kontekstu społecznego związanego z konformizmem, poczuciem zależności, wsparciem. Po drugie, wydaje się, że postawa orientująca się na teraźniejszość może być pewną strategią wyboru $\mathrm{w}$ ramach postrzegania świata, albo odzwierciedleniem pasywnej adaptacji do sytuacji utraty kontroli nad zdarzeniami. Podobnie jak strategia indywidualistyczna - może być postawą niezależnego „gracza strategicznego" albo świadectwem trudności adaptacyjnych do kontekstu społecznego. Po trzecie, „plany życiowe” stanowią kategorię zdecydowanie szerszą od tych tylko perspektyw, które można uzyskać dzięki podjęciu studiów (praca, dochody, prestiż), w związku z czym zakres czynników wpływających na szanse ich realizacji jest znacznie szerszy niż tylko uzyskane wykształcenie wyższe (szczęście, pochodzenie, kontekst instytucjonalny, koniunktura gospodarcza i inne). Decyzje edukacyjne maturzystów związane z postrzeganiem wartości wyższego wykształcenia oraz oceną szans realizacji planów w mieście lub regionie zamieszkania mają istotne znaczenia dla kształtowania lokalnej polityki edukacyjnej w związku z potencjalnymi 
procesami migracyjnymi (szczególnie w sąsiedztwie atrakcyjnego ośrodka) lub procesami rezygnacji $\mathrm{z}$ aspiracji edukacyjnych, które mogą stanowić przeszkodę w rozwoju społecznym i kulturowym regionu.

\section{ANEKS}

\section{Nota metodologiczna}

Specyfikacja badania. Wyniki badania pochodzą z cyklicznego projektu „Matura i co dalej?”, który był realizowany w latach 2010, 2013 i 2015 w ramach prac Koła Naukowego Socjologów Instytutu Socjologii na Uniwersytecie w Białymstoku. W przygotowaniu koncepcji badania, opracowaniu ankiety, organizacji badania w szkołach średnich Białegostoku brali udział asystenci z Zakładu Metodologii Badań Społecznych i Statystki Alicja Zawistowska i Łukasz Kiszkiel. Ankietę przeprowadzono w formie audytoryjnej w klasach maturalnych w liceach i technikach Białegostoku na przełomie marca i kwietnia uzyskując w 2010 roku - 1138, w 2013 - 716, a w 2015 roku - 1231 ankiet.

Analiza czynnikowa. W ankiecie przedstawiono maturzystom listę 32 stwierdzeń. Zadaniem badanych była ocena na ile stwierdzenia odnoszą się do nich osobiście, dobrze oddają ich poglądy. Ocenę badani wyrażali na pięciostopniowej skali: Zdecydowanie się zgadzam (5), Raczej się zgadzam (4), Ani się zgadzam, ani się nie zgadzam (3), Raczej się nie zgadzam (2), Zdecydowanie się nie zgadzam (1). Macierz kowariancji poddano analizie czynnikowej przy użyciu pakietu SPSS, wyodrębniając czynniki metodą głównych składowych (principal components) oraz stosując rotację Varimax. Czynniki tworzą niezależne od siebie (ortogonalne) zmienne o rozkładzie normalnym standaryzowanym. Nazwy czynników odnoszą się do treści zmiennych składających się na silnie skorelowane wiązki wskaźników. W tym sensie można traktować „czynnik” jako skalę mierzącą ukryty wymiar, którego wskaźnikami, symptomami są odpowiedzi respondentów na zadawane pytania. Przyjęto konwencję identyfikacji czynnika przez pozytywne korelacje ze wskaźnikami. Negatywne wartości ładunków czynnikowych można relatywne opisać przez negację nazwy czynnika. Wyróżnione czynniki „wyjaśniają” 50\% wariancji zmiennej stanowiącej sumę wszystkich wskaźników.

Regresja logistyczna. Zmienne zależne (przewidywane) przyjmują wartości 1 - wybór danej cechy, 0 - odrzucenie, pominięcie. Można więc interpretować zmienną zależną jako prawdopodobieństwo wyboru 
(szansy - przypadku cech pozytywnie ocenianych, pożądanych lub ryzyka - w przypadku cech negatywnych, niepożądanych). Na przykład w tabeli 3, możliwość kontynuacji nauki na studiach wyższego stopnia jest dla 41,2\% badanych okolicznością „bardzo ważną”. Model regresji logistycznej, w której zmiennymi niezależnymi (predyktorami) są czynniki, pozwala zidentyfikować czynniki istotne wpływające na zwiększenie lub zmniejszenie skłonności do wyboru (wskazywania) tej cechy oferty edukacyjnej. Współczynnik $\operatorname{EXP}(\mathrm{B})$ ma prostą interpretację. $\operatorname{Gdy} \operatorname{EXP}(\mathrm{B})>0$, np. 1,181, to można mówić, że wzrost wartości tego czynnika o jednostkę (odchylenie standardowe) od wartości średniej zwiększa szansę wskazania danej cechy o $18,1 \%$. Gdy $\operatorname{EXP}(B)<0$, na przykład 0,893, to wzrost wartości czynnika na jednostkę, wpływa negatywnie na szasnę wyboru danej cechy, o $-11 \%$. W przypadku $\operatorname{EXP}(\mathrm{B})=1$ współczynniki regresji liniowej $\mathrm{B}=0$, co oznacza, że kowariancja czynnika i zmiennej zależnej jest równa zero. Nie zachodzi związek statystyczny między zmiennością czynnika a obserwowanym zachowaniem, stanem. Użycie czynników w modelu regresyjnym spełnia dodatkowe, istotne założenia w liniowym modelu regresyjnym: czynniki mają rozkład normalny i są niezależne, spełnione jest w konsekwencji założenie addytywności wpływów w modelu regresyjnym oraz adekwatność klauzuli ceteris paribus.

\section{Literatura}

Kamieniecka, M. (2015), Decyzje edukacyjno-zawodowe uczniów szkół gimnazjalnych. Raport podsumowujący, Warszawa.

NIK (2013), Przeciwdziałanie zjawiskom patologii wśród dzieci i młodzieży szkolnej. NIK, KNO-4101-03-00, Warszawa.

Sawiński Z., 2008: Zmiany systemowe a nierówności $w$ dostęie do wykształcenia, [w:] Zmiany stratyfikacji społecznej w Polsce, red. H. Domański, Warszawa.

Sobol-Kwapińska M. (2013), Hedonism, fatalism and 'carpe diem': Profiles of attitudes toward the present time, „Time and Society”, nr 22(3).

Sobol-Kwapińska M., Jankowski T., Przepiorka A. (2016), What do we gain by adding time perspective to mindfulness? Carpe Diem and mindfulness in a temporal framework, „Personality and Individual Differences”, nr 93.

Szymański Mirosław J. (2013), Socjologia edukacji. Podręcznik akademicki, Kraków

Węziak-Białowolska, D., (2010), Model kapitału intelektualnego regionu. Koncepcja pomiaru i jej zastosowanie, Warszawa.

Węziak-Białowolska D., Kotowska I. E. (2014), Pomiar kapitału ludzkiego i jego zróżnicowanie wedlug cech demograficznych, społecznych i ekonomicznych, [w:] Rynek pracy 
Decyzje edukacyjne maturzystów. Kontekst społeczny i indywidualne postawy młodzieży... 41

i wykluczenie społeczne w kontekście percepcji Polaków - Diagnoza Społeczna 2013. Raport tematyczny, red. I. E. Kotowska, Warszawa.

Zahorska M. (2004), Zmiany w oświacie - koncepcje i uwarunkowania, [w:] Reformy społeczne. Bilans dekady, red. M. Rymsza, Warszawa.

Zawistowska A. (2012), Horyzontalne nierówności edukacyjne we współczesnej Polsce, Warszawa.

Zawistowska A. (2014), Black box of the educational reform in Poland, "Polish Sociological Review", nr 3.

\section{SUMMARY}

\section{Educational decisions of high school graduates. The social context and individual attitudes of the youths of Bialystok to the higher education.}

The aim of the article is to identify attitudes towards higher education of graduates of high schools in Białystok and to identify the individual and social factors influencing these attitudes. The decision-making model presented in the article included the personal preferences, peer groups, teachers and parents as a factors determining the value of higher education, the criteria of study selection and the expectations associated with them. The decision-making process associated with the choice of an educational path has a nature of investment decisions that are highly unpredictable because of delaying desired outcomes. That's why the decision-making process of graduates of high schools have to be highly social in nature.

KEYWORDs: school graduate, attitude to education, Carpe Diem Syndrome, decision strategies 